\title{
ANALISIS KAUSALITAS ANTARA IHSG, INDEKS DOW JONES INDUSTRIAL AVERAGE DAN NILAI TUKAR RUPIAH/US\$
}

\author{
Khairina Natsir' ${ }^{1}$, Yusbardini² ${ }^{2}$ Nurainun Bangun ${ }^{3}$ \\ ${ }^{1}$ Fakultas Ekonomi, Universitas Tarumanagara, Jakarta \\ Email: khairinan@fe.untar.ac.id \\ ${ }^{2}$ Fakultas Ekonomi, Universitas Tarumanagara, Jakarta \\ Email: yusbardini@fe.untar.ac.id \\ ${ }^{3}$ Fakultas Ekonomi, Universitas Tarumanagara, Jakarta \\ Email: inun66@yahoo.com
}

\begin{abstract}
ABSTRAK
Penelitian ini bertujuan untuk menginvestigasi hubungan kausalitas antara IHSG, nilai tukar rupiah/US\$ dan Indeks Global yang diwakili oleh Indeks Dow Jones Industrial Average. Penelitian mengambil sampel nilai-nilai variabel yang diteliti dengan periode data bulanan dalam periode Juli 2005-Desember 2018. Alat analisis menggunakan uji Engle-Granger untuk menginvestigasi hubungan kausalitas. Hasil Uji kausalitas Granger memperlihatkan terdapat hubungan dua arah atau saling mempengaruhi antara IHSG dengan nilai rupiah/US\$. Selain itu ditemukan pula bahwa pergerakan Indeks Dow Jones Industrial secara signifikan mempengaruhi kepada pergerakan IHSG dan nilai tukar rupiah/US\$, tetapi sebaliknya pergerakan yang terjadi pada IHSG dan nilai tukar tidak mampu mempengaruhi gerakan indeks Dow Jones Industrial. Hasil Uji kointegrasi Johansen memperlihatkan bahwa semua variabel penelitian mempunyai hubungan keseimbangan jangka panjang yang signifikan.
\end{abstract}

Kata kunci: kausalitas, kointegrasi, IHSG, nilai tukar rupiah/US\$, Indeks Dow Jones

\begin{abstract}
This study aims to investigate the causality relationship between the CSPI, the exchange rate of rupiah / US $\$$ and the Global Index represented by the Dow Jones Industrial Average. The study sampled variable values studied with monthly data periods in the period July 2005-December 2018. The analysis tool uses the EngleGranger test to investigate causality relationships. Granger causality test results show there is a two-way relationship or influence each other between the CSPI with the value of rupiah / US \$. In addition it was also found that the movement of the Dow Jones Industrial Index significantly affected the movement of the JCI and the exchange rate of the rupiah / US \$, but conversely the movements that occurred on the JCI and the exchange rate were unable to influence the movement of the Dow Jones Industrial index. Johansen's cointegration test results show that all research variables have a significant long-term balance relationship.
\end{abstract}

Keywords: causality, cointegration, CSPI, rupiah / US \$ exchange rate, Dow Jones Index

\section{PENDAHULUAN}

\section{Latar Belakang}

Kegiatan berinvestasi adalah suatu aktivititas mengalokasikan uang atau sumberdaya lainnya dengan harapan memperoleh manfaat di masa depan. Bermacam-macam jenis investasi digunakan oleh para investor, misalnya investasi dalam barang berharga seperti emas, properti, trading saham dan lain sebagainya.

Indeks Harga Saham Gabungan (IHSG) merupakan suatu acuan awal bagi seorang investor sebagai pertimbangan untuk ikut serta berinvestasi di bursa saham Indonesia, karena dari IHSG dapat diperkirakan situasi pasar saham secara umum. Hal ini dimungkinkan karena IHSG merupakan indeks gabungan dari berbagai jenis saham yang terdaftar di bursa efek, sehingga 
IHSG sering digunakan sebagai indikator dalam menilai kondisi pasar saham secara umum atau mengukur apakah harga saham mengalami kenaikan atau penurunan.

Seorang investor ingin mendapatkan keuntungan yang besar dan berusaha meminimalkan resiko investasinya. Oleh sebab itu, penting bagi investor untuk mengamati gerakan indikator ekonomi makro yang dapat mendukung keputusan investasinya. Pada penelitian yang dilakukan oleh Parulian \& Subartini (2013), disebutkan bahwa ada beberapa indikator ekonomi makro yang berpengaruh terhadap pasar modal Indonesia, antara lain growth GDP, produksi industri, tingkat inflasi, tingkat suku bunga, nilai tukar rupiah, tingkat penggangguran dan defisit anggaran. Pada penelitian ini pembahasan tentang IHSG akan dibatasi pada keterkaitannya dengan indeks saham Dow Jones Industrial Average, dan nilai tukar rupiah per dolar Amerika.

Perkembangan luar biasa dalam teknologi informasi menyebabkan semakin terintegrasinya perekonomian antar satu negara lain di seluruh dunia, termasuk Indonesia. Investasi akan mengalir tanpa hambatan antara bursa saham dunia. Jika suatu negara sistem keuangannya memburuk maka investor dapat memindahkan aliran dananya ke bursa negara lain dengan mudah. Apabila investasi mereka tersebar di beberapa negara maka resiko investasi dikala terjadi memburuknya situasi keuangan di suatu negara dapat dikompensasi dengan melakukan diversifikasi investasi pada bursa negara lainnya.

Dalam kasus umum, integrasi pasar saham dapat dilihat sebagai situasi dimana ketika pasar saham menunjukkan dinamika yang sama maka akan memiliki hasil yang diharapkan sama (Kangina, Knyazev, Lepekhin, \& Shemyakin, 2016).

Tidak dapat dipungkiri bahwa Amerika Serikat saat ini masih menjadi kiblat bagi kemajuan ekonomi dunia. Ketika ekonomi AS memburuk maka dalam sekejap akan segera menular kepada kondisi ekonomi negara lain. Demikian juga dengan pasar sahamnya. Perubahan yang terjadi pada indeks utama di Amerika Serikat biasanya direspon oleh indeks saham negara lain. Indeks saham manca negara yang sering menjadi incaran para investor adalah indeks Dow Jones Industrial Average (DJI). "The dow" dibangun dengan menyertakan 30 perusahaan-perusahaan industri top di Amerika Serikat yang telah go public dan terkenal dengan istilah blue chip.

Satu instrumen lain yang sangat diperhatikan oleh dunia usaha dan para investor adalah masalah nilai tukar, seperti yang terjadi akhir-akhir ini dimana nilai tukar rupiah/US\$ mencapai angka Rp 14.000an. Nilai tukar yang terdepresiasi akan membebani perusahaan karena meningkatnya pembiayaan dunia usaha dan menurunnya profit. Bagi investor melemahnya rupiah terhadap UUS\$ merupakan suatu sinyal negatif dan harus dihindari karena berpotensi resiko bagi investasi mereka. Karena itu para investor saham lebih senang mencari aman dengan melakukan aksi jual saham yang ada di perusahan-perusahaan yang terdaftar di Bursa Efek Indonesia. Buntutnya adalah nilai IHSG akan melemah.

Teori tentang pengaruh nilai tukar terhadap IHSG ini diperkuat oleh penelitian yang dilakukan oleh Vidiyanna Rizal Putri yang meneliti tentang hubungan dinamis antara nilai tukar rupiah dengan IHSG dengan menggunakan metode korelasi Pearson. Hasil penelitian tersebut memperlihatkan bahwa nilai tukar mempunyai korelasi dengan IHSG (Vidiyanna Rizal Putri, 2015). Di sisi lain, Abidin et al melakukan penelitian tentang keterkaitan antara exchange rate dengan indeks saham negara-negara Asia Pasific. Data yang digunakan adalah indeks saham dan nilai tukar currency setiap negara tehadap US\$. Hasil penelitian menunjukkan bahwa tidak ada kointegrasi (hubungan jangka panjang) antara indeks saham di negara New Zealand, 
Hongkong, Australia, Korea Selatan dan Indonesia. Tidak ada pengaruh nilai tukar terhadap indeks saham pada setiap negara, demikian juga sebaliknya indeks saham tidak mempengaruhi kepada exchange rate. Hanya di Jepang terdapat kointegrasi dan pengaruh dua arah antara exchange rate dengan indeks saham di negara tersebut (Abidin, Walters, Lim, \& Banchit, 2013). Penelitian lainnya yang dilakukan oleh Khan \& Ali, (2016) tentang kausalitas variabel fluktuasi nilai tukar mata uang rupee/US\$ dengan indeks saham KSE-100 di Pakistan memperlihatkan hasil bahwa terdapat hubungan dua arah antara kedua variabel penelitian.

Tujuan penelitian ini adalah untuk menginvestigasi hubungan kausalitas antara IHSG, Dow Jones Industrial Index, dan nilai tukar rupiah/ US\$

\section{Keterkaitan Pasar Modal Dunia}

Secara garis besar terdapat dua pemahaman mengenai integrasi (keterkaitan) dari global capital market (pasar modal dunia). Pemahaman pertama mengacu kepada teori Capital Asset Pricing Model, yang mengatakan bahwasanya beberapa pasar modal dikategorikan terintegrasi jika surat berharga yang mempunyai sifat resiko yang sama akan mempunyai harga yang sama, meskipun diperjualbelikan di bursa saham yang berbeda (Kane \& Marcus, 2011). Dengan perkataan lain, jika terdapat beberapa capital market yang terintegrasi maka surat berharga yang identik seyogianya memiliki harga yang sama di keseluruh capital market yang terintegrasi tersebut.

Pemahaman lainnya berkenaan dengan kepustakaan terbaru tentang integrasi pasar modal yang menggunakan model timeseries GARCH, Granger Causality dan VAR yang menyatakan bahwa beberapa pasar modal disebut terintegrasi jika pasar modal tersebut mempunyai keseimbangan (keterkaitan) yang berlanjut (Amir Nasry Rofael Armonius, 2013). Dengan perkataan lain, adanya pergerakan bersama diantara satu pasar modal dengan pasar modal lainnya, menandakan terdapatnya keterkaitan antar pasar modal tersebut. Integrasi atau saling terkaitnya beberapa pasar modal dapat mengacu kepada situasi dimana seorang investor dapat membeli atau menjual surat berharga yang dikeluarkan oleh suatu negara dimanapun tanpa adanya pembatasan. Makna dari adanya integrasi antar pasar modal ini adanya kesetaraan dari surat-surat berharga yang sejenis, setelah mengalami penyesuaian dengan nilai tukar mata uang lokal (Pieper \& Vogel, 1997).

\section{Indeks Harga Saham Gabungan}

Keadaan pasar modal suatu negara dapat dijadikan sebagai salah satu indikator kemajuan ekonomi negara tersebut (Tandelilin, 2013). Indeks saham atau indeks pasar saham adalah ukuran nilai dari pasar saham pada keadaan tertentu. Indeks Saham dihitung dari harga saham yang dipilih. Indeks Saham merupakan alat yang digunakan oleh investor dan manajer keuangan untuk menggambarkan pasar dan untuk membandingkan laba atas investasi tertentu. (Al-Majali \& Al-Assaf, 2014). Saat ini di Bursa Efek Indonesia terdapat 22 jenis indeks saham (www.idx.co.id). Indeks saham terbesar di BEI adalah Indeks Harga Saham Gabungan (IHSG) yang mengukur pergerakan semua saham yang terdaftar di BEI.

Pergerakan nilai IHSG yang merefleksikan keadaan seluruh saham di Bursa Efek Indonesia mendapat pengaruh variabel-variabel makro ekonomi di Indonesia. Oleh karena itu seorang investor harus jeli dan sensitif terhadap turun naiknya dan keterkaitan antara nilai beberapa indikator tersebut agar cepat dalam pengambilan keputusan investasi (Tandelilin, 2013).

Penghitungan IHSG yang sering dipakai menurut Ang (1997) terdiri dari 2 metode:

1. Metode nilai rata-rata. Yaitu metode dimana IHSG dihitung berdasarkan harga pasar saham yang terdaftar tersebut ditotalkan dan dibagi dengan suatu faktor pembagi. 
IHSG $=\frac{\sum \text { Harga Pasar }}{\text { Divisor }} \times 100,($ Sumber $:$ www.idx.co.id)

2. Metode rata-rata tertimbang (Weighted Average Method). Yaitu suatu cara perhitungan dimana mengikutsertakan pembobotan untuk perhitungan Indeks selain harga pasar dan harga dasar saham. Besarnya pembobotan disini berdasarkan kepada jumlah saham yang dikeluarkan.

\section{Indeks Dow Jones Industrial Average}

Indeks Dow Jones Industrial Average (DJI), sering disebut sebagai "Dow Jones" atau hanya sebagai "Dow," adalah rata-rata tertimbang harga saham dari 30 perusahaan besar Amerika yang diperdagangkan secara publik. Dibangun oleh Charles Dow pada tahun 1896, DJI merupakan Indeks saham AS yang paling terkenal dan digunakan untuk mengukur kinerja pasar dari hari ke hari. Dalam kasus Dow Jones Industrial Average, harga dari semua 30 saham dalam Indeks ditambahkan bersama-sama dan kemudian dibagi dengan "pembagi Dow," yang nilainya berubah seiring waktu karena pembagian saham dan peristiwa lainnya. Pembagi jauh kurang dari satu, itulah mengapa nilai Indeks lebih besar daripada jumlah harga saham.

\section{Nilai Tukar Rupiah/US\$}

Nilai tukar merupakan harga relatif dari satu jenis mata uang relatif terhadap mata uang lainnya (atau kelompok mata uang). Turun naiknya nilai tukar rupiah melawan mata uang US\$ memengaruhi aktivitas ekonomi, inflasi, dan neraca pembayaran negara, karena Amerika merupakan salah satu negara pasar eksport yang penting untuk produk-produk Indonesia. Pertukaran mata uang telah didefinisikan oleh banyak peneliti dalam studi masa lalu. Menurut Abbas (2010) melalui (Bagh, Azad, Razzaq, Liaqat, \& Khan, 2017) nilai tukar mata uang mengacu kepada nilai mata uang suatu negara terhadap negara lain.

Sudah sering diperdebatkan bahwasanya terdapat keterkaitan antara nilai tukar dan Indeks saham, terutama dalam konteks mobilitas dan lintas batas dana investasi. Terdapat dua teori yang mendukung keberadaan hubungan yang signifikan antara nilai tukar dan IHSG. Pendekatan-pendekatan ini adalah pendekatan tradisional dan portofolio. Pendekatan tradisional menyatakan bahwa ketika nilai tukar rupiah terhadap dolar Amerika melemah maka perusahaan yang bergerak dalam eksport ke luar negeri akan menjadi lebih kuat karena harga penjualan eksport yang mereka terima menjadi lebih besar ketika di konversi ke rupiah, sehingga perusahaan akan membukukan profit yang tinggi, sehingga akhirnya menghasilkan kenaikan harga saham mereka. Jadi dapat disimpulkan dari teori sebelumnya bahwa ketika mata uang rupiah terdepresiasi akan mendorong kenaikan IHSG. Tetapi sebaliknya, jika suatu perusahaan bergerak di bidang import dari luar negeri, maka ketika rupiah terdepresiasi akan menyebabkan pembengkakan biaya pembelian bahan baku, sehingga biaya produksi akan meningkat. Akibatnya terjadi penurunan laba perusahaan. Hal ini akan biasanya akan dianggap sebagai sinyal negatif oleh investor sehingga terjadi aksi jual saham-saham mereka. Pendekatan portofolio dijelaskan oleh Branson (1983) melalui Al-Majali \& Al-Assaf (2014) yang menyatakan bahwa perubahan positif dalam Indeks saham memotivasi investor untuk berinvestasi lebih banyak dalam aset domestik dan akan menghasilkan peningkatan dalam mata uang domestik. Branson juga menemukan bahwa nilai tukar dipicu oleh perubahan Indeks saham dengan hubungan berkorelasi negatif. Branson merekomendasikan suatu model nilai tukar yang stock oriented, dimana nilai tukar berfungsi untuk menciptakan keseimbangan antara penawaran dan permintaan untuk aset seperti saham dan obligasi. Studi pertama kali yang meneliti keterkaitan antara harga saham dan nilai tukar dilakukan oleh Franck and Young pada 
tahun 1972 dimana menggunakan enam nilai tukar yang berbeda dan tidak menemukan hubungan antara kedua variabel keuangan ini (Franck \& Young, 1972).

Menurut Hutasoit, sebagian besar industri di Indonesia masih tergantung kepada impor bahan baku produksi dari luar negeri. Akibatnya sangat berat dirasakan ketika mata uang rupiah terdepresiasi, sebab hal ini akan mengakibatkan kenaikan pada biaya pembelian faktor produksinya (Hutasoit, 2018). Meningkatnya biaya produksi akan menyebabkan tingkat keuntungan perusahaan akan turun. Bagi investor, menurunnya profit perusahaan dipandang sebagai sinyal negatif (Issahaku, Ustarz, \& Bata, 2013). Hal ini akan mendorong investor untuk melakukan aksi jual terhadap saham-saham yang dimilikinya sehingga berpotensi terjadinya penurunan IHSG di Bursa efek Indonesia.

\section{Keterkaitan IHSG dengan Nilai Tukar Rp/US\$}

Ketika rupiah terdepresiasi terhadap US\$ maka itu merupakan sinyal bahwa ekonomi Indonesia sedang melemah. Rupiah yang terdepresiasi pada umumnya akan menimbulkan biaya yang besar bagi perusahaan karena harus membeli bahan baku dari luar negeri dengan harga yang lebih tinggi akibat harga dolar yang semakin tinggi, sehingga biaya produksi menjadi lebih mahal. Para investor cenderung untuk menghindari resiko saham dan memikirkan untuk berinvestasi pada portofolio lain yang lebih aman atau menunggu sampai situasi perekonomian cukup stabil. Untuk mengamankan investasinya mereka akan melakukan aksi jual saham. Aksi menjual saham yang dilakukan akan berdampak pada menurunnya IHSG di BEI (Joesoef \& Rizal, 2007).

\section{Keterkaitan IHSG dengan Indeks Dow Jones}

Indeks Dow Jones Industrial Average (DJI) merupakan salah satu Indeks saham utama di Amerika Serikat. Indeks Dow Jones Industrial Average dikenal sebagai simbol kekuatan keuangan Amerika Serikat, yang selalu menjadi buruan para investor, analis dan trader. Sebagai sebuah Indeks besar yang beranggotakan 30 perusahaan yang sangat likuid di Amerika Serikat, DJI merupakan cerminan dari keadaan ekonomi Amerika Serikat. Apabila DJI menguat hal tersebut mengindikasikan sehatnya ekonomi Amerika Serikat. Sebagai sebuah negara yang merupakan tujuan eksport utama dari produk-produk Indonesia, maka kondisi keuangan Amerika Serikat tentu sangat berpengaruh kepada pertumbuhan ekonomi Indonesia. Indeks DJI yang menguat dipercaya dapat memberikan influence positif bagi saham di Indonesia. Karena itu naik atau turunnya Indeks DJI akan diikuti pula naik atau turunnya IHSG. Argumen ini sesuai dengan hasil penelitian Ruth Christa dan Wahyu Ario Pratomo yang memperlihatkan bahwa Indeks DJI berpengaruh secara signifikan terhadap IHSG (Christa \& Pratomo, 2015). Penelitian lain dilakukan oleh (Hamam, 2017) memperlihatkan bahwa pengaruh DJI terhadap IHSG adalah negatif pada jangka pendek dan jangka panjang

\section{Perumusan Masalah}

Berdasarkan latar belakang dan analisis yang sudah dipaparkan diatas, maka perumusalan masalah penelitian ini dijabarkan sebagai berikut:

1. Bagaimana hubungan kausalitas antara IHSG, Indeks Dow Jones Industrial Average dan Nilai Tukar Rupiah/US\$

2. Bagaimana hubungan jangka panjang antara IHSG, Indeks Dow Jones Industrial Average dan Nilai Tukar Rupiah/US\$

\section{Hipotesis Penelitian}

Berdasarkan kajian empiris dan teoritis yang telah dipaparkan di atas, maka hipotesis pada penelitian ini yaitu : 
$\mathrm{H}_{1}$ : Terdapat hubungan kausalitas antara IHSG, Indeks Dow Jones Industrial Average dan Nilai Tukar Rupiah/US\$

$\mathrm{H}_{2}$ : Terdapat hubungan jangka panjang antara IHSG, Indeks Dow Jones Industrial Average dan Nilai Tukar Rupiah/US\$

\section{METODE PENELITIAN}

Penelitian ini merupakan penelitian deskriptif kuantitatif menggunakan data timeseries periode bulanan 2005:7- 2018:12. Operasionalisasi Variabel diperlihatkan pada tabel 1 berikut ini.

Tabel 1. Daftar Operasional Variabel

\begin{tabular}{|l|l|l|}
\hline \multicolumn{1}{|c|}{ Tipe Variabel } & \multicolumn{1}{|c|}{ Nama Variabel } & \multicolumn{1}{c|}{ Simbol } \\
\hline Endogen/exogen & Indek Harga Saham Gabungan & IHSG \\
\hline Endogen/exogen & Indek Dow Jones Industrial Average & DJI \\
\hline Endogen/exogen & Nilai Tukar Rupiah/US\$ & KURS \\
\hline
\end{tabular}

Tahapan yang dilakukan untuk analisis data secara ringkas disajikan dalam gambar berikut ini:

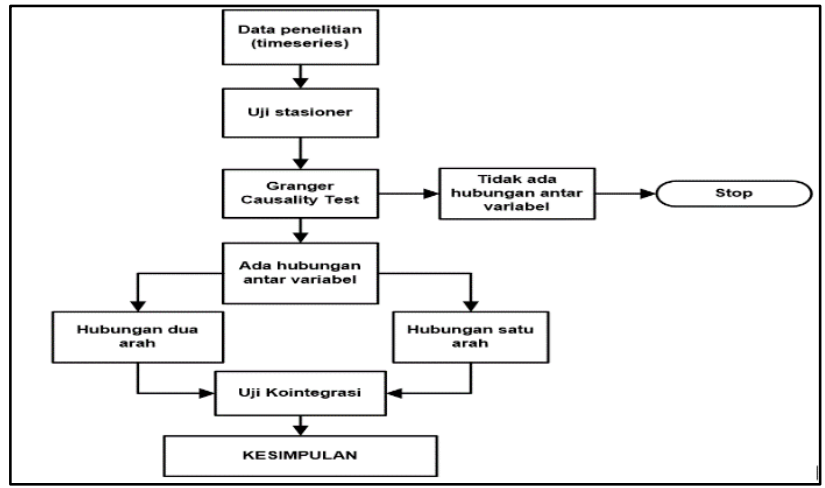

Gambar 1. Tahapan Analisis data

\section{Uji Stasioneritas}

Data timeseries disebut stasioner jika terpenuhi syarat kriteria mean dan varian yang konstan sepanjang waktu dan kovarian yang hanya tergantung dari lag. Pada penelitian ini stasioneritas data diuji menggunakan Augmented Dickey-Fuller (ADF) dengan formula sebagai berikut:

$\Delta Y_{t}=\gamma Y_{t-1}+\sum_{i=2}^{p} \beta_{i} \Delta Y_{t-i+1}+e_{t}$

Ketentuan dalam pengambilan keputusan yaitu apabila nilai mutlak statistik ADF $>$ dari critical value, maka data timeseries tersebut tidak stasioner, sementara apabila nilai mutlak statistik ADF $\geq$ dari critical value, maka data timeseries tersebut adalah stasioner.

\section{Uji Granger Causality}

Model persamaan Granger Causality antara variabel X dan Y diformulasikan sebagai berikut (Widarjono, 2013):

$Y_{t}=\sum_{i=1}^{n} a_{i} Y_{t-i}+\sum_{i=1}^{n} \beta_{i} X_{t-i}+e_{1 t}$

$X_{t}=\sum_{i=1}^{m} \delta_{i} X_{t-i}+\sum_{i=1}^{m} \varphi_{i} Y_{t-i}+e_{2 t}$

Keputusan apakah $\mathrm{Y}$ mempengaruhi $\mathrm{X}$ dan sebaliknya apakah $\mathrm{X}$ mempengaruhi $\mathrm{Y}$ diperoleh dengan menggunakan uji $\mathrm{F}$. Nilai $\mathrm{F}$ dihitung dengan formula sebagai berikut :

$F=\frac{S S R_{R}-S S R_{u} / q}{S S R_{u} /(n-k)}$ 


\section{Uji Kointegrasi}

Uji kointegrasi dimaksudkan untuk menginvestigasi kemungkinan terdapatnya hubungan jangka panjang yang stabil (long run equilibrium) diantara parameter yang diamati. Dalam uji kointegrasi diinvestigasi nilai residual regresi apakah sudah mencapai stasioner atau belum. (Anh, Dong, Kreinovich, \& Thach, 2018) menyebutkan bahwa variabel $\mathrm{x}_{\mathrm{t}}$ dan $\mathrm{y}_{\mathrm{t}}$ disebut mempunyai keseimbangan jangka panjang (ekuilibrium) jika terdapat error term yang bersifat stasioner yang dihasilkan dari kombinasi linier dari $\mathrm{x}_{\mathrm{t}}$ dan $\mathrm{y}_{\mathrm{t}}$ pada tingkat keterkaitan yang sama. Sebaliknya, jika error term tidak bersifat stasioner maka tidak ditemukan kondisi ekuilibrium.

Uji statistik kointegrasi dapat dilakukan menggunakan Trace test, dengan formulasi sebagai berikut:

$\lambda_{\text {trace }}(r)=-T \sum_{i=r+i}^{p} \ln \left(1-\lambda_{i}\right)$

dimana $\lambda_{\mathrm{r}+1}, \ldots, \lambda_{\mathrm{n}}$ adalah nilai eigenvectors terkecil $(\mathrm{p}-\mathrm{r})$.

Hipotesis pengujian adalah:

$\mathrm{H}_{0}$ : banyaknya vektor kointegrasi $(\mathrm{r})=0$

$\mathrm{H}_{1}$ : banyaknya vektor kointegrasi $(\mathrm{r})>0$

Ketentuan dalam pengambilan keputusan yaitu apabila nilai trace statistic $>$ nilai kritis pada $\alpha$ $=5 \%$ atau nilai prob $<5 \%$ ) maka hipotesis nol ditolak, yang artinya terdapat kointegrasi.

\section{HASIL DAN PEMBAHASAN}

\section{Analisis Stasioneritas Data}

Penelitian ini menggunakan uji ADF untuk menguji ada tidaknya sifat stasioner pada data. Untuk menjaga stabilitas data maka pengujian dilakukan berdasarkan kepada logaritma data penelitian. Hipotesis pengujian ini adalah:

- $\mathrm{H}_{0}$ : data tidak bersifat stasioner

- $\mathrm{H}_{1}$ : data bersifat stasioner

Hasil pengujian stasioneritas data diperlihatkan pada tabel 2 berikuti ini:

Tabel 2. Hasil uji stasioner data

Sumber: Pengolahan data penelitian

\begin{tabular}{lcccccc}
\hline \multicolumn{6}{c}{ Uji Stasioneritas Augmented Dickey-Fuller } \\
\hline \multirow{2}{*}{ Variabel } & \multicolumn{5}{c}{ Level } & \multicolumn{3}{c}{ 1 $^{\text {st }}$ Difference } \\
\cline { 2 - 7 } & Adj. T-Stat & Prob. ${ }^{*}$ & Keterangan & Adj. T-Stat & ${\text { Prob. }{ }^{*}}$ & Keterangan \\
\hline L_IHSG & -2.879494 & 0.2496 & Tdk stasioner & -2.879494 & 0.0000 & Stasioner \\
\hline L_DJI & -2.879380 & 0.9587 & Tdk stasioner & -2.879494 & 0.0000 & Stasioner \\
\hline L_KURS & -2.879610 & 0.9107 & Tdk stasioner & -2.879610 & 0.0000 & Stasioner \\
\hline
\end{tabular}

Hasil uji pada level dengan metode ADF memperlihatkan bahwa bahwa semua nilai Prob* > level of significance $(\alpha=0.05)$, maka secara statistik dapat dikatakan bahwa tidak mampu untuk menolak $\mathrm{H}_{0}$, sehingga pada level semua variabel penelitian (L-DJI, L_IHSG, L_KURS) tidak stasioner. Pada variabel yang tidak stasioner pada tahap level harus dilanjutkan uji stasioner ke tahap $1^{\text {st }}$ difference. Hasil uji stasioner pada $1^{\text {st }}$ difference memperlihatkan semua nilai Prob* < 0.05 , sehingga dapat disimpulkan secara statistik mampu untuk menolak $\mathrm{H}_{0}$, atau pada $1^{\text {st }}$ difference semua variabel penelitian sudah stasioner.

\section{Analisis Kausalitas Granger}

Uji kausalitas bertujuan untuk melihat pola keterkaitan antar variabel penelitian. Untuk dapat melakukan uji kausalitas terlebih dahulu harus ditentukan panjang lag yang layak digunakan. 
Lag selection dilakukan dengan beberapa metode yaitu LR, FPE, AIC, SC dan HQ. Hasil uji diperlihatkan pada tabel berikut ini.

Tabel 3. Hasil pemilihan lag optimal

Sumber: Hasil pengolahan data

\begin{tabular}{ccccccc}
\hline Lag & LogL & LR & FPE & AIC & SC & HQ \\
\hline 0 & 72.98330 & NA & $8.09 \mathrm{e}-05$ & -0.908874 & -0.849713 & -0.884843 \\
\hline 1 & 927.8567 & 1665.338 & $1.37 \mathrm{e}-09$ & -11.89424 & -11.65760 & -11.79812 \\
\hline 2 & 965.9642 & $72.75057^{*}$ & $9.39 \mathrm{e}-10^{*}$ & $-12.27226^{*}$ & $-11.85813^{*}$ & $-12.10404^{*}$ \\
\hline 3 & 974.9262 & 16.76015 & $9.40 \mathrm{e}-10$ & -12.27177 & -11.68015 & -12.03146 \\
\hline 4 & 981.9334 & 12.83132 & $9.66 \mathrm{e}-10$ & -12.24589 & -11.47679 & -11.93348 \\
\hline 5 & 990.6907 & 15.69497 & $9.70 \mathrm{e}-10$ & -12.24274 & -11.29615 & -11.85824 \\
\hline 6 & 1000.312 & 16.86797 & $9.63 \mathrm{e}-10$ & -12.25080 & -11.12673 & -11.79421 \\
\hline 7 & 1002.867 & 4.380195 & $1.05 \mathrm{e}-09$ & -12.16710 & -10.86555 & -11.63841 \\
\hline 8 & 1011.628 & 14.67753 & $1.06 \mathrm{e}-09$ & -12.16400 & -10.68496 & -11.56322 \\
\hline * indicates lag order selected by the criterion & & & &
\end{tabular}

Penentuan lag optimal dilihat dari kemungkinan nilai $L R, F P E, A I C, S C$ dan $H Q$ yang memiliki tanda bintang (*). Hasil pengujian memberikan hasil bahwa lag optimal yaitu pada lag 2. Hasil uji kausalitas Granger dengan lag 2 berupa tabel yang menunjukkan indeks dan variabel-variabel yang berpengaruh terhadap setiap indeks tersebut dapat dilihat pada tabel 4 di bawah.

Dari hasil pengujian kausalitas Granger, suatu variabel dikatakan mempengaruhi variabel lainnya secara signifikan apabila Prob $<0.05$. Berdasarkan hal tersebut dari hasil uji yang diperlihatkan pada Tabel 4, pergerakan IHSG dipengaruhi secara signifikan dengan arah positif oleh pergerakan Indeks Dow Jones dan pergerakan nilai tukar, artinya apabila indeks Dow Jones naik maka IHSG juga akan ikut naik, demikian juga apabila nilai tukar terapresiasi maka IHSG akan ikut naik, demikian juga sebaliknya.

Tabel 4. Hasil Uji Granger Causality

Sumber: Hasil pengolahan data

\begin{tabular}{|c|c|c|c|}
\hline \multicolumn{4}{|c|}{ Dependent variable: L_IHSG } \\
\hline Excluded & Chi-sq & df & Prob. \\
\hline L DJI & 11.82821 & 2 & 0.0027 \\
\hline L_KURS & 12.95390 & 2 & 0.0015 \\
\hline \multicolumn{4}{|c|}{ Dependent variable: L_DJI } \\
\hline Excluded & Chi-sq & df & Prob. \\
\hline L IHSG & 3.189823 & 2 & 0.2029 \\
\hline L_KURS & 2.591320 & 2 & 0.2737 \\
\hline \multicolumn{4}{|c|}{ Dependent variable: $L$ LUURS } \\
\hline Excluded & Chi-sq & df & Prob. \\
\hline L_IHSG & 29.34654 & 2 & 0.0000 \\
\hline L DJI & 7.193094 & 2 & 0.0274 \\
\hline
\end{tabular}

Hasil uji kausalitas juga memperlihatkan bahwa pergerakan nilai tukar (Kurs) dipengaruhi secara signifikan arah positif oleh pergerakan IHSG dan juga pergerakan Indeks Dow Jones. Ini berarti kenaikan yang terjadi pada IHSG ataupun indeks Dow Jones akan menyebabkan terapresiasinya nilai tukar rupiah, sebaliknya jika IHSG atau Dow Jones tertekan, maka nilai tukar juga akan ikut tertekan.

Disisi lain, hasil uji kausalitas memperlihatkan bahwa variabel IHSG dan nilai tukar tidak mempu mempengaruhi pergerakan indeks Dow Jones. Hal ini dapat dimengerti mengingat Dow Jones adalah sebuah indeks besar yang justru menjadi kiblat bagi pasar saham lainnya.

\section{Analisis Uji Kointegrasi}

Seperti yang dipaparkan oleh (Engle, Granger, \& Mar, 2007), eksistensi variabel yang nonstasioner menghadirkan kemungkinan besar terdapatnya kaitan jangka panjang antar variabel. Berkaitan dengan hal ini, maka langkah berikutnya yaitu melakukan uji kointegrasi untuk menginvestigasi keberadaan keterkaitan jangka panjang antar variabel (Widarjono, 2013). 
Pengujian kointegrasi pada penelitian ini mengadopsi Johanson System Cointegration Test. Hasil pengujian dengan eigenvalue dan Trace Statistic diperlihatkan sebagai berikut:

Tabel 5. Hasil Uji Kointegrasi

\begin{tabular}{|c|c|c|c|c|}
\hline \multicolumn{5}{|c|}{ Unrestricted Cointegration Rank Test (Trace) } \\
\hline $\begin{array}{l}\text { Hypothesized } \\
\text { No. of } C E(s)\end{array}$ & Eigenvalue & $\begin{array}{l}\text { Trace } \\
\text { Statistic }\end{array}$ & $\begin{array}{c}0.05 \\
\text { Critical Value }\end{array}$ & Prob.** \\
\hline None * & 0.288415 & 95.26560 & 29.79707 & 0.0000 \\
\hline At most $1 *$ & 0.230088 & 41.50435 & 15.49471 & 0.0000 \\
\hline At most 2 & 0.001206 & 0.190610 & 3.841466 & 0.6624 \\
\hline
\end{tabular}

Dari hasil pengujian menggunakan Trace Statistic menunjukkan bahwa pada hipotesis pertama $\mathrm{R}=0$ (none) dan hipotesis kedua $\mathrm{R} \leq 1$ (at most 1 ) diperoleh Prob $=0.0000(<0.05)$, sehingga $\mathrm{H}_{0}$ ditolak, atau terdapat keberadaan kointegrasi atau hubungan (ekuilibrium) jangka panjang antar variabel-variabel penelitian.

\section{Pembahasan.}

1. Berdasarkan hasil uji kausalitas Granger ditemukan kausalitas positif IHSG dengan nilai tukar Rp/US\$. Hasil penelitian ini mendukung kepada penelitian yang dilakukan oleh Syakhroza \& Endri (2012) yang meneliti hubungan kausalitas IHSG dan nilai tukar di 5 negara Asean. Hasil penelitian tersebut meperlihatkan bahwa pasar saham dan pasar valas Filipina mempunyai hubungan kausalitas. Penelitian Vidiyanna Rizal Putri (2015) memperlihatkan bahwa IHSG berkorelasi dengan nilai tukar. Hasil penelitian ini tidak konsisten dengan penelitian yang dilakukan oleh Rosnawintang (2018) yang menyatakan bahwa hubungan antara IHSG dengan nilai tukar adalah hubungan searah dimana IHSG yang memberikan pengaruh signifikan kepada nilai tukar. Dengan adanya hubungan kausalitas positif antara nilai tukar dan IHSG maka peran pemerintah sangat diharapkan dalam menjaga stabilitas nilai tukar agar investor tetap mempercayakan investasinya di pasar modal Indonesia.

2. Berdasarkan hasil uji Kointegrasi Johansen di atas diperoleh temuan bahwa terdapat keberadaan hubungan jangka panjang yang signifikan antara IHSG, Indeks Dow Jones nilai tukar rupiah/US\$ selama periode penelitian. Hasil ini tidak konsisten dengan penelitian yang dilakukan oleh (Giani \& Dalimunthe (2014) yang memperlihatkan bahwa dalam jangka panjang tidak terdapat hubungan antara IHSG dengan nilai tukar Rp/US\$, dan penelitian yang dilakukan oleh Abidin et al. (2013) yang menyatakan bahwa tidak ada kointegrasi dan pengaruh dua arah antara exchange rate dengan indeks saham di Bursa Efek Indonesia. Di tengah keadaan pasar yang terus melemah, maka investor akan memilih melakukan trading jangka pendek dan memperhatikan saham secara individual dan memilih saham yang sedang memiliki momentum baik. Oleh karena itu perusahaan harus berusaha untuk menjaga stabilitas kinerjanya.

3. Hasil pengujian memperlihatkan tidak ada hubungan kausalitas maupun kointegrasi antara IHSG dengan indeks Dow Jones, maupun antara nilai tukar dengan indeks Dow Jones. Hasil ini berbeda dengan hasil penelitian Wibowo, (2012) yang menyatakan adanya hungan kausalitas antara IHSG dengan Indeks Dow Jones. Hasil ini dapat digunakan untuk menarik investor ke Bursa Saham Indonesia saat krisis ekonomi di Amerika karena ketika Amerika dilanda krisis ekonomi, Indonesia belum tentu akan mengalami hal yang sama. 


\section{KESIMPULAN DAN SARAN}

Berdasarkan masalah yang dirumuskan dan penelitian yang telah dilakukan, maka dapat dibuat kesimpulan sebagai berikut :

a. Hasil uji kausalitas Granger antara variabel penelitian menunjukkan bahwa variabel IHSG dan variabel nilai tukar rupiah/US\$ mempunyai hubungan kausalitas dua arah (saling mempengaruhi) secara signifikan dengan arah positif selama periode pengamatan.

b. Hasil uji kausalitas Granger menunjukkan variabel Indeks Dow Industrial mempengaruhi secara signifikan dan arah positif terhadap pergerakan IHSG dan nilai tukar, tetapi tidak ada satupun dari variabel IHSG dan nilai tukar Rp/US\$ yang signifikan mempengaruhi pergerakan Dow Jones Index.

c. Hasil Uji kointegrasi Johansen memperlihatkan terdapat kointegrasi atau hubungan jangka panjang yang signifikan antar IHSG, nilai tukar rupiah/US\$ dan Indeks Dow Jones.

Implikasi dari hasil penelitian yang diperoleh adalah:

Terdapatnya hubungan yang positif antara IHSG dengan nilai tukar ditengah kondisi keuangan Indonesia yang masih belum stabil akan memberi dampak negatif kepada keberadaan investasi di Bursa Efek Indonesia. Jika nilai tukar atau IHSG menurun akan menyebabkan investor akan berhati-hati untuk berinvestasi, yang pada gilirannya akan berdampak buruk pada laba perusahaan. Karena itu diperlukan upaya terus menerus agar nilai tukar atau IHSG selalu dalam keadaan stabil.

\section{Ucapan Terima Kasih (Acknowledgement)}

Terima kasih saya sampaikan kepada Direktur DPPM dan Dekan FEB Universitas Tarumanagara yang telah memberikan dukungan sehingga makalah ini dapat dipresentasikan pada SNRM 2019.

\section{REFERENSI}

Abbas, Z. (2010). Dynamics of Exchange Rate and Stock index: A Study on Emerging Asian Economies. Mohammad Ali Jinnah University, Islamabad.

Abidin, S., Walters, C., Lim, K.-L., \& Banchit, A. (2013). Cointegration between stock prices and exchange rates in Asia-Pacific Cointegration between stock prices and exchange rates in Asia-Pacific countries. Investment Management and Financial Innovations, 10(2).

Al-Majali, A. A., \& Al-Assaf, G. I. (2014). Long-run and short-run relationship between stock market index and main macroeconomic variables performance in Jordan. European Scientific Journal, 10.

Amir Nasry Rofael Armonius. (2013). Globalization Effect On Stock Exchange Integration. In Meeting of Young Researchers Around the Mediterranean, Tarragona (p. 9). Cairo University. Retrieved from https://papers.ssrn.com/sol3/papers.cfm?abstract_id=1929045

Ang, R. (1997). Buku Pintar Pasar Modal Indonesia (The Intelligent Guide to Indonesian Capital Market). Jakarta: Mediasoft Indonesia.

Anh, L. H., Dong, L. S., Kreinovich, V., \& Thach, N. N. (2018). Studies in Computational Intelligence 760 Econometrics for Financial Applications. Vietnam: Springer International Publishing AG 2018.

Bagh, T., Azad, T., Razzaq, S., Liaqat, I., \& Khan, M. A. (2017). The Impact of Exchange Rate Volatility on Stock Index: Evidence from The Impact of Exchange Rate Volatility on Stock Index : Evidence from Pakistan Stock Exchange ( PSX ). International Journal of Academic Research in Accounting, Finance and Management Sciences, 7(September), 7086. https://doi.org/10.6007/IJARAFMS/v7-i3/3150

Branson, W. H. (1983). A model of exchange-rate determination with policy reaction: evidence from monthly data. National Bureau of Economic Research. 
Christa, R., \& Pratomo, W. A. (2015). Analisis Pengaruh Indeks Harga Saham di Bursa Global terhadap Indeks Harga Saham Gabungan di BEI. Jurnal Ekonomi Dan Keuangan, 1(8).

Engle, R. F., Granger, C. W. J., \& Mar, N. (2007). Co-Integration and Error Correction : Representation , Estimation, and Testing. Econometrica, 55(2), 251-276.

Franck, P., \& Young, A. (1972). Stock price reaction of multinational firms to exchange realignments. Financial Management, 2, 66-73.

Giani, T. H., \& Dalimunthe, Z. (2014). Hubungan antara Indeks Harga Saham dan Nilai Tukar Rupiah-Dolar Amerika Serikat Periode 2001-2013: Dengan Kerangka Kointegrasi dan Hubungan Kausalitas. Jakarta: Universitas Indonesia.

Hamam, M. R. W. I. (2017). Analisis Kointegrasi Dan Pengaruh Antara Beberapa Pasar Modal Dunia Terpilih Terhadap Pasar Modal Indonesia. UMY.

Hutasoit, S. (2018). Kenapa Harus Impor Bahan Baku Industri. Retrieved August 11, 2019, from https://www.tubasmedia.com/kenapa-harus-impor-bahan-baku-industri-2

Issahaku, H., Ustarz, Y., \& Bata, P. D. (2013). Macroeconomic Variables And Stock Market Returns in Ghana : Any Causal Link ? Asian Economic and Financial Review, 3(8), 1044 1062. Retrieved from http://aessweb.com/journal-detail.php?id=5002

Joesoef, \& Rizal, J. (2007). Pasar Uang dan Valuta Asing. Jakarta: Salemba Empat.

Kane, B. Z., \& Marcus, A. (2011). Investments and portofolio Management. Global Edition. New York: The McGraw-Hill Companies,.

Kangina, N., Knyazev, A., Lepekhin, O., \& Shemyakin, A. (2016). Modeling joint distribution of national stock indices, $11,15-26$. https://doi.org/10.3233/MAS-150350

Khan, R. E. A., \& Ali, R. (2016). Causality Analysis of Volatility in Exchange Rate and Stock Market Prices: A Case Study of Pakistan. Asian Economic and Financial Review, 5(5), 805-815. https://doi.org/10.18488/journal.aefr/2015.5.5/102.5.805.815

Parulian, Y. H., \& Subartini, B. (2013). Analisis Pengaruh IHSG , Inflasi , BI Rate dan Nilai Tukar Rupiah terhadap Fluktuasi Harga Saham Bank Di Indonesia Menggunakan Metode Regresi Linear Berganda, 9(1), 19-27.

Pieper, P., \& Vogel, R. (1997). The Stock Market Integration In Latin America. CAER II Discussion Paper No. 21.

Rosnawintang. (2018). Hubungan Kausalitas Nilai Tukar, Suku Bunga dan Indeks Harga Saham di indonesia. Jurnal Ekonomi Pembangunan., 7(2), 29-45.

Syakhroza, A., \& Endri. (2012). Hubungan Kausalitas Harga Saham dan Nilai Tukar di NegaraNegara Asean-5. FInance and Banking Journal, 14(2), 17-31.

Tandelilin, T. (2013). Portofolio dan Investasi: Teori dan Aplikasi. Yogyakarta: Kanisius.

Vidiyanna Rizal Putri. (2015). Hubungan dinamis antara nilai tukar rupiah dan inflasi dengan indeks harga saham di BEI. Jurnal Ekonomi, Manajemen Dan Perbankan, 1(3), 110-119.

Wibowo, H. (2012). Analisis Kointegrasi Pasar Modal In Donesia Dengan Pasar Modal Amerika Serikat Dan Pasar Modal Eropa Menggunakan Pendekatan Johansen Cointegration Test (Studi Kasus pada saat terjadi Krisis Ekonomi di Amerika Serikat dan Eropa tahun 2008 2012). Jurnal Bisnis Strategi, 21(1), 112-141.

Widarjono, A. (2013). Model Koreksi Kesalahan. In Ekonometrika: Pengantar dan Aplikasinya (4th ed., p. 305). Yogyakarta: UPP STIM YKPN. 